\title{
Dimethylsulphide (DMS) emissions from the western Pacific Ocean: a potential marine source for stratospheric sulphur?
}

\author{
C. A. Marandino ${ }^{1}$, S. Tegtmeier ${ }^{1}$, K. Krüger ${ }^{1}$, C. Zindler ${ }^{1}$, E. L. Atlas ${ }^{2}$, F. Moore ${ }^{3}$, and H. W. Bange ${ }^{1}$ \\ ${ }^{1}$ GEOMAR Helmholtz-Zentrum für Ozeanforschung Kiel, Düsternbrooker Weg 20, 24105 Kiel, Germany \\ ${ }^{2}$ RSMAS/MAC, University of Miami, 4600 Rickenbacker Causeway, Miami, FL 33149, USA \\ ${ }^{3}$ NOAA/Earth System Reasearch Laboratory (NOAA/ESRL), 325 Broadway, Boulder, CO 80305-3337, USA
}

Correspondence to: C. A. Marandino (cmarandino@geomar.de)

Received: 19 November 2012 - Published in Atmos. Chem. Phys. Discuss.: 26 November 2012

Revised: 28 June 2013 - Accepted: 9 July 201 - Published: 26 August 2013

\begin{abstract}
Sea surface and atmospheric measurements of dimethylsulphide (DMS) were performed during the TransBrom cruise in the western Pacific Ocean between Japan and Australia in October 2009. Air-sea DMS fluxes were computed between 0 and $30 \mu \mathrm{mol} \mathrm{m} \mathrm{m}^{-2} \mathrm{~d}^{-1}$, which are in agreement with those computed by the current climatology, and peak emissions of marine DMS into the atmosphere were found during the occurrence of tropical storm systems. Atmospheric variability in DMS, however, did not follow that of the computed fluxes and was more related to atmospheric transport processes. The computed emissions were used as input fields for the Lagrangian dispersion model FLEXPART, which was set up with actual meteorological fields from ERA-Interim data and different chemical lifetimes of DMS. A comparison with aircraft in situ data from the adjacent HIPPO2 campaign revealed an overall good agreement between modelled versus observed DMS profiles over the tropical western Pacific Ocean. Based on observed DMS emissions and meteorological fields along the cruise track, the model projected that up to $30 \mathrm{~g} \mathrm{~S}$ per month in the form of DMS, emitted from an area of $6 \times 10^{4} \mathrm{~m}^{2}$, can be transported above $17 \mathrm{~km}$. This surprisingly large DMS entrainment into the stratosphere is disproportionate to the regional extent of the area of emissions and mainly due to the high convective activity in this region as simulated by the transport model. Thus, if DMS can cross the tropical tropopause layer (TTL), we suggest that the considerably larger area of the tropical western Pacific Ocean can be a source of sulphur to the stratosphere, which has not been considered as yet.
\end{abstract}

\section{Introduction}

Dimethylsulphide (DMS) is the most abundant naturally produced sulphur compound emitted from the sea surface. DMS has been the focus of much research since Charlson et al. (1987) proposed that DMS produced in the sea surface by phytoplankton may affect the atmospheric radiative budget via its role in aerosol and cloud formation. In addition, because DMS is rapidly oxidised when emitted to the atmosphere (mainly by the hydroxyl radical, $\mathrm{OH}$ ), studies have been conducted showing that certain DMS oxidation products can be transported above the tropopause and contribute to the persistent stratospheric sulphur layer, or Junge layer, e.g. carbonyl sulphide (Crutzen, 1976), sulphur dioxide $\left(\mathrm{SO}_{2}\right)$ (Chatfield and Crutzen, 1984), and sulphur species in general (Gondwe et al., 2003; Lucas and Prinn, 2003). Recent work has shown that an underestimation of the radiative effect of the Junge layer can lead to an overestimation of global warming (Solomon et al., 2011). Hofmann et al. (2009) reported that since 2000 there has been an increase in the aerosol backscatter above the tropopause, and they propose an increase in sulphur compounds in the atmosphere as the main cause. It has recently been shown that the influence of minor volcanic eruptions and anthropogenic loading to the atmosphere have a distinct global footprint with regard to the Junge layer (Brühl et al., 2012, Bourassa et al., 2012; Vernier et al., 2011b). However, it is most likely that a combination of sulphur sources is responsible for the observed increase in stratospheric aerosol, including a natural component that also needs to be investigated. Myhre et al. (2004) have suggested, based on model calculations, that the contribution of 


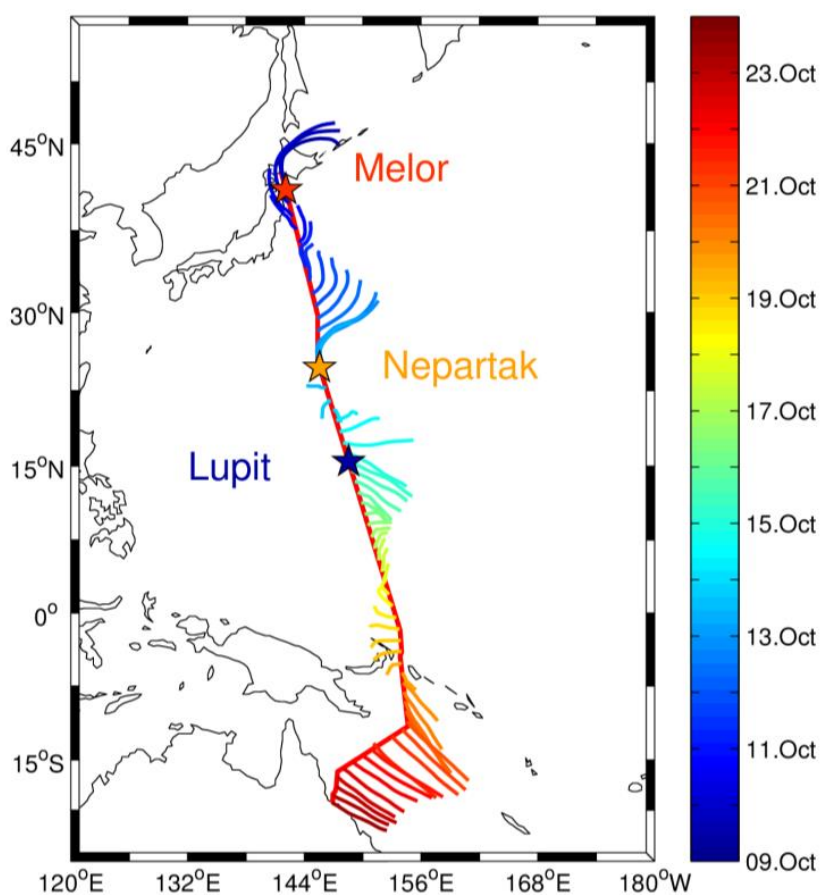

Fig. 1. TransBrom cruise track from Japan to Australia in October 2009. Coloured lines indicate one-day back trajectories for each day shown in the colour bar. Dots on the cruise track indicate the three storm events that occurred during the cruise.

sulphur to the stratosphere from marine DMS emissions may be important.

Typically surface ocean DMS emissions ( $F$, flux) are calculated using $F=k \Delta C$, where $k$ is a wind-speed-based parameterisation of the gas transfer coefficient and $\Delta C$ is the measured bulk air-sea concentration difference. Because DMS is almost always supersaturated in the surface ocean, seawater concentrations are the main component of the concentration difference. Regarding $k$ values, there is currently no consensus on the functionality of the wind speed dependence of the gas transfer coefficient. Thus, several different parameterisations have been proposed and used frequently in the literature, which lead to considerable variability in computed surface ocean trace gas fluxes (see Ho et al., 2007, for an overview). Furthermore, although remotely sensed wind speeds, with high spatial and temporal resolution, are readily available for flux calculations, it is still difficult to parameterise surface ocean DMS concentrations on similar scales. Therefore, it is necessary to use archived in situ measurements to calculate DMS emissions. Unfortunately, there is a considerable lack of high spatial and temporal resolution data for oceanic DMS. It is important to build up the current Global Surface Seawater DMS Database (http://saga.pmel. noaa.gov/dms), in conjunction with ancillary data, in order to better understand the controls on oceanic DMS and predict future air-sea fluxes. Lana et al. (2011), in the footsteps of
Kettle et al. (1999, 2000), have used the existing database to compile a current surface ocean DMS climatology and compute air-sea fluxes. However, the influence of DMS hotspots and high-wind-speed events, such as typhoons and tropical storms, on the DMS flux is hard to determine from such a climatology. Therefore, it is important to compare in situ calculations to those in the climatology, not only to make the database more robust, but also to determine the importance of such events relative to "normal" conditions.

In this paper, we use in situ measurements of $\Delta C$ and wind speed $(U)$ with three different $k$ parameterisations to compute DMS emissions during the TransBrom cruise in October 2009 in the western Pacific Ocean (Fig. 1). This oceanic region experiences several meteorological phenomena, such as tropical storms and deep convection, which make it especially significant for transporting climate-active trace gases emitted from the surface ocean to the upper troposphere/lower stratosphere. The upper part of the tropical tropopause layer (TTL), between 15 and $17 \mathrm{~km}$ altitude, is of specific interest here. The western Pacific region acts as a main entrance region of trace gases into the stratosphere, termed the "stratospheric fountain" based on cold point temperatures at $100 \mathrm{mb}$ (Newell and Gould-Stewart, 1981), throughout the year peaking during the boreal winter season with enhanced vertical transport (Fueglistaler and Haynes, 2005; Krüger et al., 2008, 2009). Since the atmospheric DMS lifetime is short, between $11 \mathrm{~min}$ and $46 \mathrm{~h}$ due to reaction with hydroxyl and nitrate radicals (e.g. Osthoff et al., 2009; Barnes et al., 2005), DMS transport to the TTL is more efficient in the western Pacific Ocean than in other oceanic regions. Recently, also in the western Pacific, an OH "hole" was observed (Rex et al., 2011), which implies an increase in the atmospheric lifetime and possible vertical transport of DMS. Furthermore, cloud and aerosol scavenging of DMS is less efficient than that of DMS oxidation products (e.g. $\mathrm{SO}_{2}$ and DMSO, Gray et al., 2011); thus convective transport of DMS could provide an in situ source for these compounds in the TTL. Computed DMS sea-to-air in situ fluxes from the TransBrom cruise to the western Pacific Ocean were used to initiate the high-resolution Lagrangian transport model FLEXPART to determine the importance of surface DMS emissions for potential stratospheric sulphur loading in this region.

\section{Data and model}

\subsection{Ship measurements}

Underway surface water samples for DMS and air samples for DMS were collected aboard the R/V Sonne from 9 to 24 October 2009 during a transit from Tomakomai (Japan) to Townsville (Australia). A detailed description of the TransBrom cruise including the meteorological background is given by Krüger and Quack (2012). Three tropical storms 


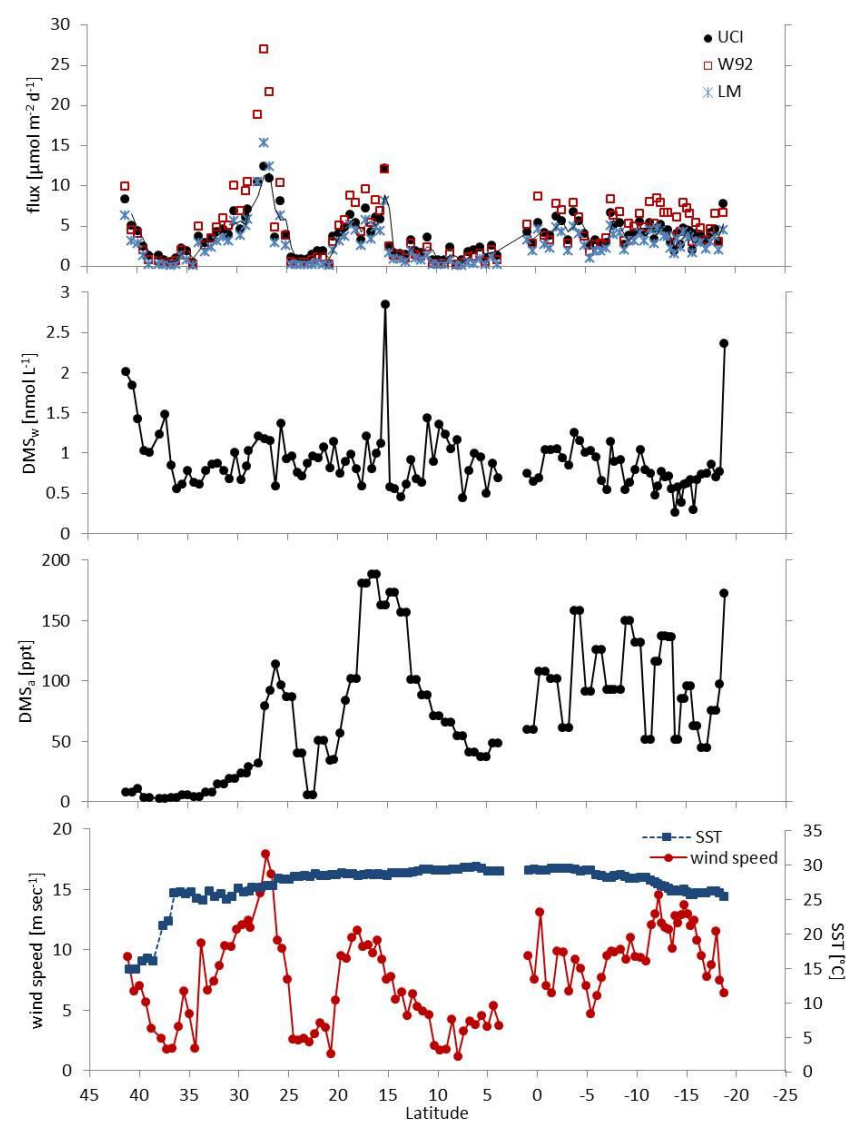

Fig. 2. Shipboard measurements and subsequent flux calculations over the TransBrom cruise track (by latitude, positive denotes northern latitudes and negative southern), from top: panel 1 computed DMS fluxes using the UCI $k$ parameterisation (UCI - solid circle), the Wanninkhof (1992) parameterisation (W92 - open square), and the Liss and Merlivat (1986) parameterisation (LM - asterix); panel 2 measured seawater DMS concentrations from Zindler et al. (2013); panel 3 measured atmospheric DMS mixing ratios; panel 4 measured horizontal wind speed (solid circle) and sea surface temperature (solid square).

(Melor, 9 October; Nepartak, 12 October; Lupit, 14 October) passed the transit and were responsible for wind speeds up to $18 \mathrm{~m} \mathrm{~s}^{-1}$ (see also Figs. 1 and 2). The circulation of the Pacific Ocean and atmosphere were affected by a strengthening El Nino event, inducing an increase in sea surface temperature towards the east, which triggered an elevated atmospheric convection towards the east and reduced the convection towards the west (Krüger and Quack, 2012). The analyses of water samples, taken every three hours, from this cruise using gas chromatography coupled to flame photometric detection are described in detail by Zindler et al. (2013). Atmospheric measurements of DMS were performed according to Schauffler et al. (1999), also with samples taken at three hour intervals. Air and water samples were not always taken simultaneously. When this occurred, the distance between the sample locations was used to determine the air and water pairs. The mean analytical errors were estimated to be $\pm 20 \%$ for dissolved DMS (Zindler et al., 2013) and $\pm 10 \%$ for atmospheric DMS.

The DMS oceanic and atmospheric data were used for the flux calculation. Sea surface temperature and wind speed data from ship sensors at one-minute resolution were selected dependent on time and latitude of the DMS samples (Fig. 2). Flux calculations were performed by applying three different gas transfer coefficient parameterisations at a Schmidt number of 720, that of DMS in seawater at $25^{\circ} \mathrm{C}$ according to Saltzman et al. (1993): Marandino et al. (2007) - UCI; Wanninkhof (1992) - W92; Liss and Merlivat (1986) - LM. The parameterisations were chosen to reflect the different theories of wind speed dependence and measurement techniques for $\mathrm{k}$, where UCI is linear and derived from eddy covariance measurements, W92 is quadratic and derived from the ${ }^{14} \mathrm{C}$ ocean inventory, and LM contains three different linear parameterisations based on tracer studies and wind/wave tank measurements.

\subsection{Model runs}

The atmospheric transport of DMS from the oceanic surface into the upper troposphere and the TTL is simulated with the Lagrangian particle dispersion model FLEXPART (Stohl et al., 2005). This model has been widely applied to simulate long-range and mesoscale transport (e.g. Spichtinger et al., 2001; Stohl et al., 2003; Forster et al., 2004) and extensively validated based on measurement data from three large-scale tracer experiments (Stohl et al., 1998) and on intercontinental air pollution transport studies (e.g. Stohl and Trickl, 1999; Forster et al., 2001). FLEXPART is an off-line model driven by meteorological fields from the European Centre for Medium-Range Weather Forecast (ECMWF) numerical weather prediction model. It includes the simulation of chemical decay based on a prescribed atmospheric lifetime, parameterisations for moist convection (Forster et al., 2007), turbulence in the boundary layer and free troposphere (Stohl and Thompson, 1999), dry deposition and in-cloud, as well as below-cloud, scavenging.

In order to quantify the amount of DMS transported into the upper TTL for the observations during the TransBrom campaign, we simulate the transport pathways (trajectories) of a multitude of air parcels starting at the ship measurement time and location. For each computed DMS in situ sea-to-air flux a separate FLEXPART run is launched where 10000 air parcels were released over one hour from a $0.0002^{\circ} \times 0.0002^{\circ}$ grid box $\left(\sim 500 \mathrm{~m}^{2}\right)$ distributed along the cruise track at the ocean surface centred at the measurement location. Based on the computed DMS in situ flux, the total amount of DMS emitted from this grid box over one hour is calculated and uniformly distributed over all air parcels. The amount of DMS carried by each air parcel is reduced at a rate corresponding to its chemical lifetime, which is set to $12 \mathrm{~h}$ and $24 \mathrm{~h}$ to represent typical gas phase values 
found in the literature (Sect. 1), without accounting for diurnal effects (conservative approach as the lifetime is longer at night), for two model scenarios. The FLEXPART runs are driven by the ECMWF reanalysis product ERA-Interim (Dee et al., 2011) using 6-hourly meteorological data. The input fields of horizontal and vertical wind, temperature, specific humidity, convective and large-scale precipitation, among other parameters, are given at a horizontal resolution of $1^{\circ} \times 1^{\circ}$ on 60 model levels. The vertical wind input data retrieved from ECMWF is calculated in hybrid coordinates mass-consistently from spectral data using a pre-processor.

For the validation of the FLEXPART runs, we compare simulated DMS abundances with available aircraft observations from the HIAPER Pole to Pole Observations (HIPPO) 2 campaign, which were collected during several flight missions over the Pacific Ocean during October/November 2009 (http://hippo.ornl.gov/; Wofsy et al., 2012). For this intercomparison, additional FLEXPART runs were launched applying the actual meteorological fields for the time of the HIPPO2 campaign during November 2009, but using the DMS emissions from the TransBrom cruise during October 2009 since we do not have observed DMS emissions for November 2009. For these runs an average DMS emission of $1.54 \times 10^{-7} \mathrm{~mol} \mathrm{~m}^{-2} \mathrm{~h}^{-1}$ was distributed uniformly over the tropical oceans (within $30^{\circ} \mathrm{S}-30^{\circ} \mathrm{N}$, see Sect. 3.1 for a discussion of the computed fluxes and comparison to current climatologies) and the atmospheric DMS transport was calculated for November 2009. Additionally, the same global runs were carried out for October and December 2009 to estimate temporal (month-to month) variations of the DMS entrainment into the stratosphere.

The level above which no significant washout is expected is of special importance for the transport of DMS to the stratosphere. DMS and its oxidation products reaching this altitude can be assumed to contribute to the stratospheric sulphur loading irrespective of their remaining chemical lifetime. While the exact vertical extent of the region where significant washout is expected is still under debate (Fueglistaler et al., 2009), we have chosen the cold point temperature at around $17 \mathrm{~km}$ as the upper estimate of this level. The cold point tropopause altitude was confirmed during TransBrom with regular 6-hourly radiosonde measurements (Quack and Krüger, IFM-GEOMAR Cruise Report No. 37, 2010). Additionally, we evaluate DMS entrainment above $15 \mathrm{~km}$, which is well above the main convective outflow regions and close to the level of zero radiative heating.

For the surface air mass origin, one-day backward trajectories have been calculated online with the HySplit model using the meteorological fields from National Centers for Environmental Prediction - Global Data Assimilation System (NCEP-GDAS). Detailed technical information about the trajectory model version 4 can be found in Draxler and Hess (2004).

\section{Results and discussion}

\subsection{Atmospheric concentrations and computed DMS air-sea fluxes}

Marine boundary layer atmospheric mixing ratios of DMS ranged between 2 and $200 \mathrm{ppt}(76.2 \pm 52.2 \mathrm{ppt})$, which are in the low to average range for open ocean background mixing ratios of DMS (Fig. 2). Previous measurements of atmospheric DMS around the area of the TransBrom cruise track are in general agreement, $26.6 \pm 16.1 \mathrm{ppt}, 19.3 \pm 14.7 \mathrm{ppt}$, $42.4 \pm 26.9 \mathrm{ppt}$, and $59.3 \pm 16.8 \mathrm{ppt}$, but were measured during May-June (Kato et al., 2007; Marandino et al, 2007). DMS values measured in the marine boundary layer, during the adjacent HIPPO2 aircraft campaign (discussed in Sect. 3.2), were between 0 and 100 ppt during November 2009. One-day back trajectory analysis shows that the first 5 days of the ship cruise were influenced by continental air masses from Asia, the next 6 days experienced back trajectories from the open ocean (the 11th day, just south of the Equator, had air masses originating over the Soloman Islands), and the air in the last 4 days originated from eastern Australia or the Tasman Sea (Fig. 1). The largest atmospheric DMS abundances were observed at approximately $16^{\circ} \mathrm{N}$, when the cruise encountered the tropical storm Nepartak. However, the highest values that were not influenced by major storm events were found towards the end of the cruise track, in the air regime influenced by the Tasman Sea.

DMS fluxes were computed using the shipboard measurements of atmospheric and surface ocean concentrations (discussed by Zindler et al., 2013), sea surface temperature, and horizontal wind speed (Fig. 2). Three different parameterisations were applied to compute the gas transfer coefficient: Marandino et al. (2007) - UCI; Wanninkhof (1992) - W92; Liss and Merlivat (1986) - LM. The computed fluxes vary between 3 and $30 \mu \mathrm{mol} \mathrm{m}{ }^{-2} \mathrm{~d}^{-1}$. The range of the fluxes reflects the range in the computed $k$ values, e.g. W92 employs a quadratic and UCI a linear wind speed dependence. The diversity of gas exchange parameterisations causes approximately a factor of three differences in the computed fluxes. In this study, the highest values were computed during the tropical storm Nepartak, during which the highest wind speeds (up to $18 \mathrm{~m} \mathrm{~s}^{-1}$ ) were experienced. The fluxes shown here are in the general range reported in the Lana et al. (2011) DMS climatology for October in this region. However, there are some spatial distribution differences. Lana et al. (2011) compute values between 0 and $15 \mu \mathrm{mol} \mathrm{m}^{-2} \mathrm{~d}^{-1}$, with a maximum of approximately $30 \mu \mathrm{mol} \mathrm{m}^{-2} \mathrm{~d}^{-1}$ in the Tasman Sea. Our maximum values are similar to those of Lana et al. (2011) but were observed northward of the Equator between 20 and $40^{\circ} \mathrm{N}$, directly related to storm events. The Tasman Sea values reported here did not reach the values in the Lana et al. (2011) climatology and are approximately $5 \mu \mathrm{mol} \mathrm{m}{ }^{-2} \mathrm{~d}^{-1}$. 

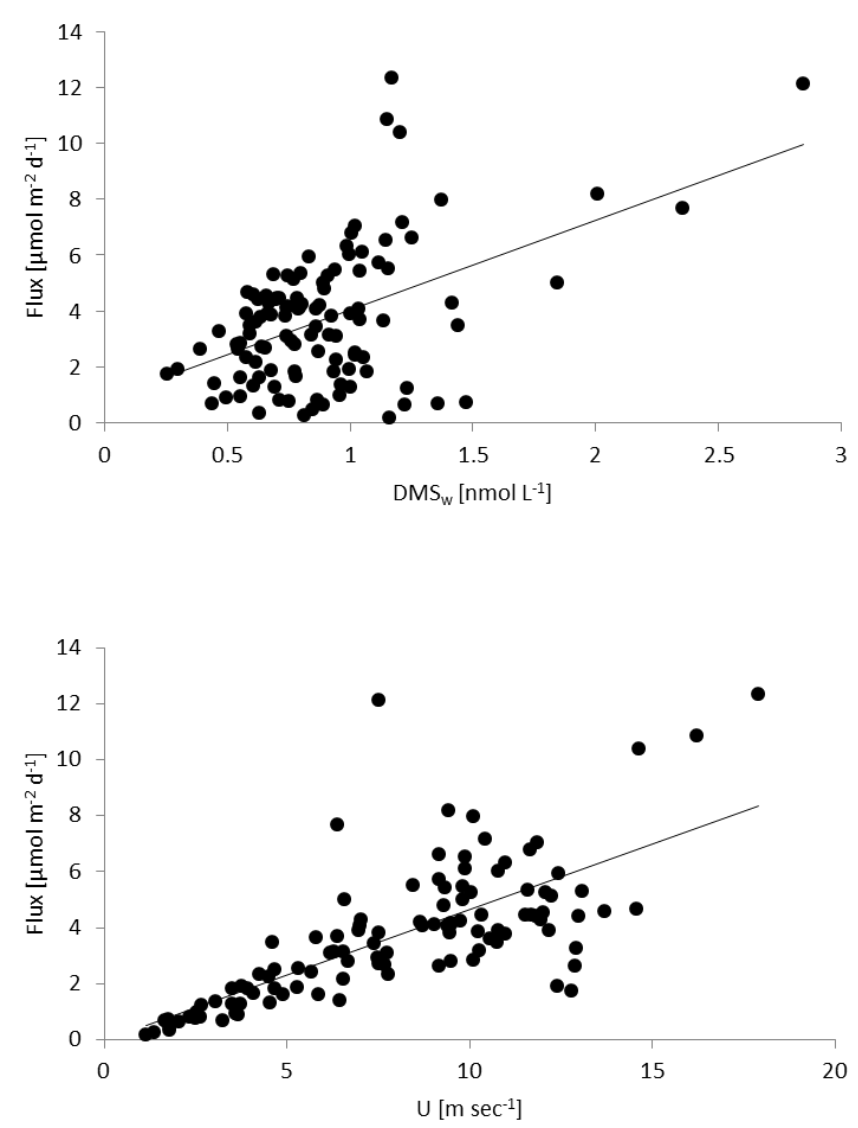

Fig. 3. Top: computed flux regressed against seawater concentration of DMS $\left(y=3.20 \times+0.84, r^{2}=0.24\right)$. Bottom: computed flux regressed again horizontal wind speed $\left(y=0.47 \times-0.00, r^{2}=0.52\right)$.

The computed fluxes in all cases correlate more with wind speed than with the seawater concentrations of DMS, especially for fluxes computed with $k$ values more strongly dependent on wind speed (Fig. 3). This may point to the fact that the gas transfer coefficient parameterisation disproportionately influences the computed fluxes. Eddy correlation measurements of DMS flux have indicated that the surface seawater DMS concentrations explain more of the variability in the directly measured fluxes than horizontal wind speed by a factor of approximately 2 (Marandino et al., 2007). Another complication surrounding the use of wind-speed-based parameterisations and measured concentrations was determined by Marandino et al. (2008). They found that directly measured emissions were up to 5 times higher than those computed using the flux equation alone, possibly reflecting a disparity between the concentration of DMS at the interface and that of the bulk water. However, Marandino et al. (2008) hypothesise that this finding may be specific to regions with high biological activity and, therefore, may not be not applicable here.
Interestingly, atmospheric values of DMS do not follow the same pattern as the computed fluxes or seawater DMS concentrations over the cruise track (Fig. 2). It is evident that the seawater concentrations of DMS do not have the same level of variability as the air values. It is very likely that the atmospheric values measured over the cruise track were more influenced by horizontal advection than by in situ fluxes. The highest fluxes were computed for the Nepartak storm event, at which time there is only a secondary maximum in the atmospheric mixing ratio. This may indicate that DMS was rapidly transported away and replaced with continental air, since back trajectories indicate a continental influence in this region. Conversely, there was a maximum peak in atmospheric values during the next tropical storm, Lupit, which was at the secondary flux maximum. During this time, back trajectory analysis indicates that air masses originated from the open ocean. There may have been a larger source region upwind, which resulted in more DMS in the atmosphere that was rapidly transported by the storm toward the cruise track.

\subsection{Implications for atmospheric sulphur loading}

The measured levels of surface ocean DMS in the western Pacific Ocean are not above the mean level of the global open ocean (Zindler et al., 2013). Considering that the patterns of atmospheric DMS mixing ratios do not follow the surface ocean concentration patterns, nor do the flux values, transport processes seem to have an important influence on DMS-derived sulphur loading to the atmosphere. In order to investigate the role of transport in more detail, the high-resolution transport model FLEXPART was used to track the fate of DMS after its emission from the ocean. As a test, the tropical DMS distribution based on average TransBrom emissions was calculated for November 2009, where in situ aircraft measurements of the HIPPO2 campaign were available above the tropical western Pacific Ocean (see Sect. 2.2 for details). FLEXPART simulations use an atmospheric DMS lifetime of 1/2-day and the output is given on a $1^{\circ} \times 1^{\circ}$ grid. Figure 4 shows the locations of the tropical HIPPO2 measurements colour coded by day. Coincident data points between the tropical HIPPO2 measurements and the FLEXPART output were identified if their distance in latitude/longitude space is less than $0.5^{\circ}$ and their altitude distance is less than $500 \mathrm{~m}$. A comparison of all identified coincidences is shown in the right panel of Fig. 4. Large parts of the vertical DMS distribution observed during the HIPPO2 campaign can be reproduced by the FLEXPART simulation. DMS values are high in the boundary layer and low above, reaching mixing ratios between 0 and 2 ppt in the lower TTL (12-14 km). Some fragment of the HIPPO2 observations shows very large values (around $200 \mathrm{ppt}$ ) at around $8 \mathrm{~km}$ altitude that are not reproduced by the FLEXPART simulations. It is very likely that these large DMS mixing ratios resulted from local convective events lifting DMS-rich air from the boundary layer into the upper troposphere. These 

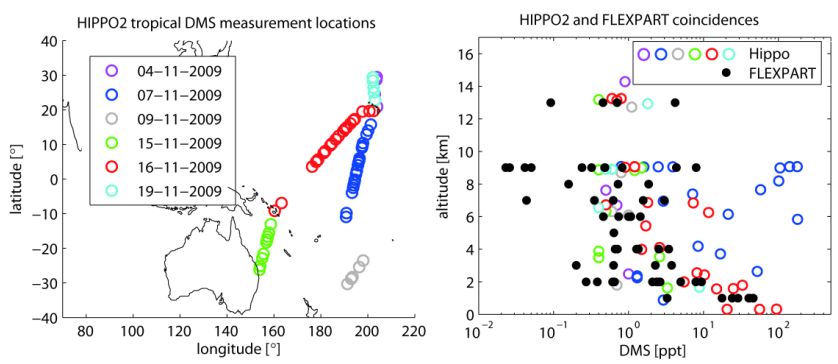

Fig. 4. Comparison between HIPPO2 atmospheric DMS observations and FLEXPART DMS simulations (1/2-day atmospheric lifetime). Measurement locations for HIPPO2 (left panel) and comparison between HIPPO2 and FLEXPART coincidences (right panel) are shown. Note: DMS (ppt) of right panel is logarithmic.

large DMS values seem to be due to an atmospheric feature that is narrow in horizontal extent. It is very likely that such small-scale features can only be reproduced using the true emission fields, which are not available for the present FLEXPART runs. The overall good agreement provides confidence in the simulated oceanic DMS contribution to the upper atmosphere using the in situ emissions from the TransBrom cruise.

In the next step, the amount of DMS transported into the TTL and to the top of the TTL was calculated using the emissions computed with the UCI air-sea gas flux approach as input for the FLEXPART simulations (Sect. 2.2). Figure 5 shows the vertical DMS distribution given as a relative quantity $(\%)$ with respect to the amount of originally emitted DMS and as a total quantity $(\mathrm{kg})$ for the $1 / 2$-day lifetime case. This vertical DMS distribution was determined for each emission event as the accumulated amount of DMS reaching the respective altitudes given on the $y$ axis. This computation does not represent a flux over a specific area with units of $\mathrm{g} \mathrm{m}^{-2} \mathrm{~h}^{-1}$, but rather the accumulation of DMS at the tropopause layer at any location the parcel may reach over the time of the cruise. Figure 5a illustrates that in most cases less than $30 \%$ of the originally emitted DMS leaves the boundary layer. With increasing altitude less DMS is found in the atmosphere, and above $12 \mathrm{~km}$ more than $10 \%$ of the originally emitted DMS can only be detected for a few isolated cases. Less than $1 \%$ DMS in nearly all cases reaches the level of $17 \mathrm{~km}$. The total amount of DMS transported from the ocean surface along the TransBrom cruise track is given in $\mathrm{kg}$ in Fig. $5 \mathrm{~b}$. Between $20^{\circ} \mathrm{N}$ and $15^{\circ} \mathrm{N}$, as well as around $5^{\circ} \mathrm{S}$, enhanced vertical transport, which is connected with intense tropical convection (Krüger and Quack, 2012), is visible in Fig. 5b (regions with yellow and red colours extending above $12 \mathrm{~km}$ ). These events coincide with medium to large DMS emissions (right side axis of panels in Fig. 5, black line) resulting in $5 \times 10^{-7}-1 \times 10^{-6} \mathrm{~kg}$ of DMS (equivalent to 3 to $10 \%$ ) reaching the upper TTL. These same events also demonstrate that more than $30 \%$ of emitted DMS can reach
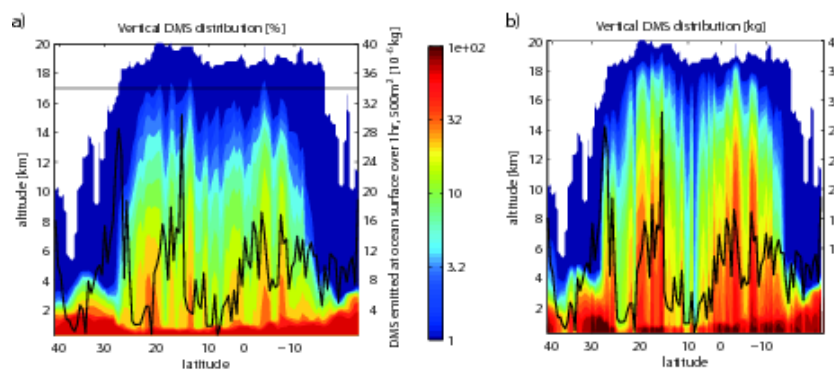

Fig. 5. Atmospheric vertical DMS distribution computed along the TransBrom cruise track given as (a) amount relative to DMS emission from the sea surface $(\%)$ and (b) total amount $[\mathrm{kg}]$. Atmospheric DMS distribution is based on FLEXPART simulations with a 1/2-day atmospheric lifetime. DMS emission at the ocean surface over $500 \mathrm{~m}^{2}$ and one hour is given as the black line corresponding to the right $y$ axis.

8 to $9 \mathrm{~km}$ altitude, where peak mixing ratios of 50 to $180 \mathrm{ppt}$ were detected by the HIPPO2 aircraft campaign (Fig. 4). It is noteworthy, however, that the pattern in emissions, namely the peak emissions, does not entirely follow the pattern of entrainment to the TTL. On the first half of the cruise, until around $10^{\circ} \mathrm{S}$, we can surmise that the storm events that triggered the large emissions do not always coincide with the high entrainment events. South of $10^{\circ} \mathrm{S}$, the pattern of seato-air fluxes is more closely linked to the pattern of entrainment. Similar results were observed for $\mathrm{CHBr}_{3}$ transport during the TransBrom cruise (Tegtmeier et al., 2012). Figure 6 shows tropical estimates of the amount of DMS transported above the level of $17 \mathrm{~km}$ for two different atmospheric DMS lifetimes ( 1 day and 1/2 day). As expected, the amount of DMS reaching $17 \mathrm{~km}$ is considerably smaller for the shorter lifetime.

Tost et al. (2010), using different convective parameterisation schemes in a global CTM, showed that the choice of the convection parameterisation has an influence on trace gas distributions. It is shown that the Emanuel parameterisation, used by FLEXPART, injects more mass across the $250 \mathrm{mb}$ surface $(\sim 11 \mathrm{~km}$ altitude) in the tropics than other convection schemes used. Therefore, it is possible that FLEXPART may show increased injected mass across the $17 \mathrm{~km}$ altitude surface in the tropics. However, the representation of convection in FLEXPART has been validated with tracer experiments and ${ }^{222} \mathrm{Rn}$ measurements in Forster et al. (2007). While observational evidence for direct convective injections into the lower stratosphere exists (e.g. Ricaud et al., 2007; Corti et al., 2008), it is not clear yet how frequent such convective overshooting events are and what their relative impact on the stratospheric composition is. The importance of convective overshooting for troposphere-stratosphere exchange has been highlighted recently by Vernier et al. (2011a), and with regard to regional importance by Sassen et al. (2008) and Nazaryan et 
Table 1. Calculation of sulphur loading above the TTL relative to the $0.015 \mathrm{Tg} \mathrm{S} \mathrm{yr}^{-1}$ required globally to maintain Junge layer after 2002 (Hofmann et al., 2009). The last column indicates the amount of sulphur reaching the TTL from the cruise track source region relative to the required amount of sulphur source to explain the observed change in the Junge layer, scaled by the size of the cruise track source region.

\begin{tabular}{lrrrrr}
\hline DMS lifetime & $\begin{array}{r}\text { DMS above 17 km } \\
(\mathrm{TgS} \text { month }\end{array}$ & $\begin{array}{r}\text { Area of } \\
\text { emissions }\left(\mathrm{m}^{2}\right)\end{array}$ & $\begin{array}{r}\text { Area of global } \\
\text { ocean }\left(\mathrm{m}^{2}\right)\end{array}$ & $\begin{array}{r}\text { required Tg S } \\
\text { month }^{-11}\end{array}$ & $\begin{array}{r}\text { Marine } \\
\text { contribution } \\
\text { (multiplying } \\
\text { factor })^{2}\end{array}$ \\
\hline $12 \mathrm{~h}$ & $1.43 \times 10^{-11}$ & $5.75 \times 10^{4}$ & $3.60 \times 10^{14}$ & $2.00 \times 10^{-13}$ & 71.5 \\
$24 \mathrm{~h}$ & $2.37 \times 10^{-11}$ & & & 119 \\
\hline
\end{tabular}

${ }^{1}$ Scaled to the area of emissions. ${ }^{2}$ DMS above $17 \mathrm{~km}$ (column 2) divided by Required Tg S month ${ }^{-1}$ (column 5).

al. (2008). Additionally, Romps and Kuang (2009) discuss the enhanced likelihood of deep convection during tropical storms, three of which were encountered on the TransBrom cruise (Krüger and Quack, 2012). On the other hand studies based on satellite data from Gettelman et al. (2002), Liu and Zipser (2005), and Rossow and Pearl (2007) argue for only little impact of deep convective overshooting with less than $1 \%$ of storms penetrating the stratosphere. Note that our model results suggest that $0.48 \%$ of the DMS emitted into the marine boundary layer will reach the stratosphere, corresponding to a delivery of $30 \mathrm{~g} \mathrm{~S}$ per month. Such a scenario suggests a mechanism where deep convection, although not important for the overall mass flux, could surprisingly enable DMS to act as a regional source for stratospheric sulphur.

These estimates of DMS entrained above $17 \mathrm{~km}$, summed over the whole TransBrom campaign, are compared to the required global annual sulphur source computed by Hofmann et al. (2009) to maintain the Junge layer during volcanically quiescent periods (Table 1). For DMS with a oneday lifetime, the average quantity transported above $17 \mathrm{~km}$ over the cruise track is approximately $6.37 \times 10^{-6} \mathrm{~kg}$ DMS $\mathrm{h}^{-1}$ or $2.37 \times 10^{-11} \mathrm{Tg} \mathrm{S}$ month $^{-1}$. The value changes to $3.84 \times 10^{-6} \mathrm{~kg}$ DMS when FLEXPART is run with the more conservative assumption of a DMS lifetime of $12 \mathrm{~h}$. The monthly mean calculation for DMS transport above $17 \mathrm{~km}$ assumes that the DMS emission field and convective processes are constant for the entire month, which is reasonable given that the cruise and FLEXPART runs extended over a 2-week period. Hoffman et al. (2009) calculate that $0.01-0.02 \mathrm{Tg} \mathrm{S} \mathrm{yr}^{-1}$ is required globally, from all the different sulphur sources, including anthropogenic sulphur and minor volcanic eruptions, to maintain the increase in the Junge layer after 2000. A value of $2.0 \times 10^{-13} \mathrm{Tg} \mathrm{S}$ month $^{-1}$ is obtained when this value is scaled down by surface area to the region of emission, i.e. 115 emission events each over $500 \mathrm{~m}^{2}\left(5.75 \times 10^{4} \mathrm{~m}^{2}\right)$ divided by the surface area of world ocean $\left(3.6 \times 10^{14} \mathrm{~m}^{2}\right)$. The amount of DMS projected to be transported to the TTL is approximately 75-119 times higher than the required amount of sulphur from Hoffman et al. (2009). This computed sulphur loading does not take into account the oxidation products of DMS that may also be transported above the TTL. Myhre et al. (2004) projected that natural sulphur emissions on a global scale contribute significantly to the Junge layer source; however they also conclude that anthropogenic emissions are the dominant factor. While their conclusions are obvious for the global scale, the regional importance of marine sulphur has been overlooked. The value computed here from the TransBrom cruise highlights that oceanic emissions of DMS in regions of fast vertical uplift play a disproportionately (when evaluated by regional size) important role in the radiative budget of the atmosphere. Modest increases in marine emissions coupled to enhancements of vertical transport or tropical cyclone activity in the tropics may easily be a main factor, on a regional scale, contributing to the higher source of sulphur discussed by Hofmann et al. (2009) to the Junge layer.

Additionally, the entrainment rates modelled by FLEXPART for the month of October are not constant over the entire year. Figure 7 illustrates the change in tropical $\left(20^{\circ} \mathrm{S}-\right.$ $20^{\circ} \mathrm{N}$ ) DMS entrainment above 15 and $17 \mathrm{~km}$ over time, from October to December 2009, based on the conservative lifetime projection of $1 / 2$ day. The FLEXPART runs use the same emission fields over the entire period, but variability in entrainment is clearly evident. This variability is only due to changes in the meteorology and hence in vertical transport processes (i.e. deep tropical convection) over time. On average, October shows lower DMS abundances at 15 and $17 \mathrm{~km}$ altitude than November and December, as would be expected from the pronounced and fast TTL transport during the boreal winter season over the western Pacific Ocean (Fueglistaler and Haynes, 2005; Krüger et al., 2009). These runs are of course only representative for 2009 and interannual variability may be even more pronounced. However, during the TransBrom period from 9 to 24 October 2009, the DMS model values can be as high as during other short-term periods for the months of November and December. Thus, we conclude that given the very short lifetime of DMS the TTL entrainment is mainly determined by synoptic-scale processes such as tropical deep convective events rather than large-scale seasonal effects. The Lana et al. (2011) flux climatology shows increased DMS emissions in the tropics seasonally, especially from December 


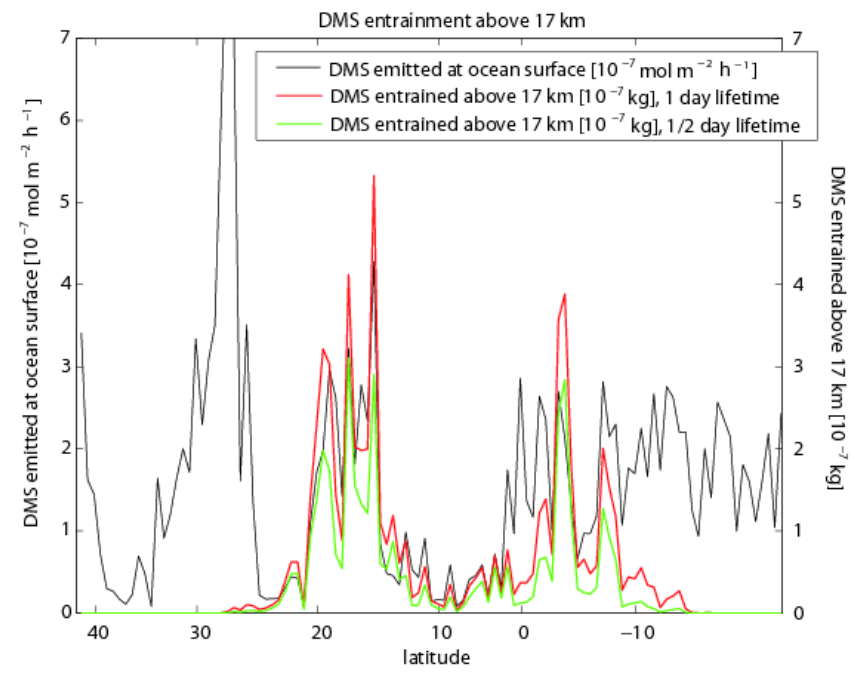

Fig. 6. Observed emissions of DMS at the ocean surface (black line), and total amount of DMS entrained above $17 \mathrm{~km}$ based on FLEXPART simulations with 1-day (red line) and 1/2-day (green line) atmospheric lifetimes shown.

to February. The emissions increase approximately 5 times over that time period, while entrainment above $17 \mathrm{~km}$ stays in the same order of magnitude and can be large for shortterm periods (Fig. 7). Scenarios in which several factors related to both emissions and meteorology background conditions (e.g. wind speed and direction, sea surface temperature) change need to be investigated in order to understand how increased marine emissions coupled with increased transport to the stratosphere may impact sulphur loading to the free troposphere as well as to the Junge layer.

\section{Conclusions}

Ship measurements of seawater and atmospheric DMS, wind speed, and sea surface temperature from October 2009 in the western Pacific Ocean, on board the TransBrom cruise, were used to compute marine emissions of DMS. The emissions were employed to model the amount of DMS that is transported to the tropical tropopause layer $(12-17 \mathrm{~km})$ in October, applying the Lagrangian transport model FLEXPART. The resulting amount of DMS to $17 \mathrm{~km}$ altitude is notable, 75-119 times greater than the required stratospheric source when scaled by the area of emissions. This amount could also increase with season, during times of higher emission, tropical cyclone or deep tropical convection activities. Given that dissolved DMS concentrations observed in the tropical western Pacific Ocean were not considerably high, it is noteworthy that the intense vertical transport in this area can deliver large quantities of DMS and, likely, its oxidation products to the TTL, where they can potentially cross into the stratosphere and (further) oxidise to form sulphate aerosol (e.g. DMS-derived methanesulphonic acid found in upper tropo-

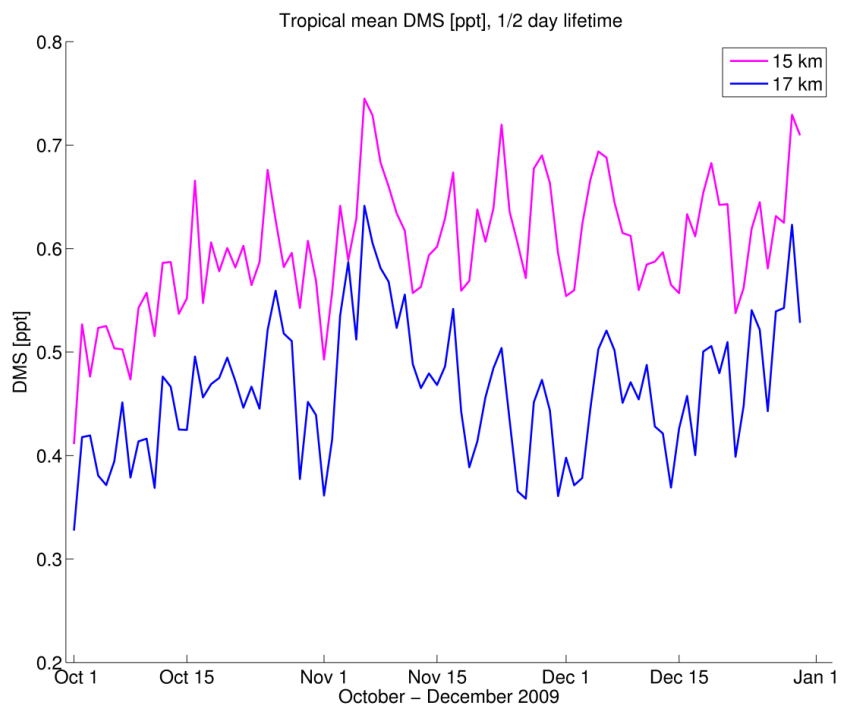

Fig. 7. Time series of tropical $\left(20^{\circ} \mathrm{S}-20^{\circ} \mathrm{N}\right)$ mean DMS volume mixing ratios at $17 \mathrm{~km}$ and $15 \mathrm{~km}$ for October to December 2009 . The time series is based on FLEXPART model simulations using TransBrom average emissions for the tropical oceans and 1/2-day atmospheric lifetime for DMS.

sphere/lower stratosphere aerosols; Froyd et al., 2009). Additional focused studies on DMS seawater concentrations and emissions are required in regions such as the western tropical Pacific Ocean in order to better quantify the full impact of marine DMS emissions on the radiative budget of the atmosphere, now and in a future climate.

Acknowledgements. We acknowledge the support of the captain and crew of R/V Sonne as well as the chief scientist of "TransBrom-Sonne", Birgit Quack. The authors are grateful for fruitful discussions with Douglas Wallace and Arne Koertzinger. We thank Franziska Wittke for assistance with the measurements of the sulphur compounds and Sebastian Wache and Steffen Fuhlbrügge for the trajectory analysis and creating Fig. 1. Financial support of this study was provided by the BMBF grant SOPRAN II FKZ 03F0462A and by the WGL project TransBrom (www.geomar.de/ transbrom). The R/V Sonne transit cruise was financed by the BMBF through grant 03G0731A. C. Marandino and C. Zindler were partly financed by Christa Marandino's Helmholtz Young Investigator Group TRASE-EC, funded by the Helmholtz Association through the President's Initiative and Networking Fund and the Helmholtz-Zentrum für Ozeanforschung Kiel (GEOMAR). Results from this work contribute to the BMBF ROMIC-THREAT grant 01LG1217A.

The service charges for this open access publication have been covered by a Research Centre of the Helmholtz Association.

Edited by: W. T. Sturges 


\section{References}

Barnes, I., Hjorth, J., and Mihalopoulos, N.: Dimethylsulfide and dimethylsulfoxide and their oxidation in the atmosphere, Chem. Rev., 106, 940-975, doi:10.1021/Cr020529, 2006.

Bourassa, A. E., Robock, A., Randel, W. J., Deshler, T., Rieger, L. A., Lloyd, N. D., Llewellyn, E. J., and Degenstein, D. A.: Large volcanic aerosol load in the stratosphere linked to asian monsoon transport, Science, 337, 78-81, doi:10.1126/science.1219371, 2012.

Brühl, C., Lelieveld, J., Crutzen, P. J., and Tost, H.: The role of carbonyl sulphide as a source of stratospheric sulphate aerosol and its impact on climate, Atmos. Chem. Phys., 12, 1239-1253, doi:10.5194/acp-12-1239-2012, 2012.

Charlson, R. J., Lovelock, J. E., Andreae, M. O., and Warren, S. G.: Oceanic phytoplankton, atmospheric sulfur, cloud albedo and climate, Nature, 326, 655-661, doi:10.1038/326655a0, 1987.

Chatfield, R. B. and Crutzen, P. J.: Sulfur-dioxide in remote oceanic air - Cloud transport of reactive precursors, J. Geophys. Res.Atmos., 89, 7111-7132, doi:10.1029/Jd089id05p07111, 1984.

Corti, T., Luo, B. P.,de Rues, M., Brunner, D., Cairo, F., Mahoney, M. J., Martucci, G., Matthez, R., Mitev, V., dos Santos, F. H., Schiller, C., Shur, G., Sitnikov, N. M., Spetlen, N., Vössing, J. J., Borrmann, S., and Peter, T.: Unprecedented evidence for deep convection hydrating the tropical stratosphere, Geophys. Res. Lett., 35, L10810, doi:10.1029/2008GL033641, 2008.

Crutzen, P. J.: The possible importance of OCS for the sulfate layer of the stratosphere, Geophys. Res. Lett., 3, 73-76, doi:10.1029/G1003i002p00073, 1976.

Dee, D. P., Uppala, S. M., Simmons, A. J., Berrisford, P., Poli, P., Kobayashi, S., Andrae, U., Balmaseda, M. A., Balsamo, G., Bauer, P., Bechtold, P., Beljaars, A. C. M., van de Berg, L., Bidlot, J., Bormann, N., Delsol, C., Dragani, R., Fuentes, M., Geer, A. J., Haimberger, L., Healy, S. B., Hersbach, H., Holm, E. V., Isaksen, L., Kallberg, P., Kohler, M., Matricardi, M., McNally, A. P., Monge-Sanz, B. M., Morcrette, J. J., Park, B. K., Peubey, C., de Rosnay, P., Tavolato, C., Thepaut, J. N., and Vitart, F.: The ERA-Interim reanalysis: configuration and performance of the data assimilation system, Q. J. Roy. Meteor. Soc., 137, 553-597, doi:10.1002/Qj.828, 2011.

Draxler, R. R. and Hess, G. D.: Description of the hysplit 4 modeling system.NOAA Technical Memorandum, ERL, ARL-224, 27 , available at: http://www.arl.noaa.gov/documents/reports/arl-224. pdf, 2004.

Forster, C., Wandinger, U., Wotawa, G., James, P., Mattis, I., Althausen, D., Simmonds, P., O’Doherty, S., Jennings, S. G., Kleefeld, C., Schneider, J., Trickl, T., Kreipl, S., Jager, H., and Stohl, A.: Transport of boreal forest fire emissions from Canada to Europe, J. Geophys. Res.-Atmos., 106, 22887-22906, doi:10.1029/2001jd900115, 2001.

Forster, C., Cooper, O., Stohl, A., Eckhardt, S., James, P., Dunlea, E., Nicks, D. K., Holloway, J. S., Hubler, G., Parrish, D. D., Ryerson, T. B., and Trainer, M.: Lagrangian transport model forecasts and a transport climatology for the Intercontinental Transport and Chemical Transformation 2002 (ITCT 2K2) measurement campaign, J. Geophys. Res.-Atmos., 109, D07s92, doi:10.1029/2003jd003589, 2004.

Forster, C., Stohl, A., and Seibert, P.: Parameterization of convective transport in a Lagrangian particle dispersion model and its evaluation, J Appl. Meteorol. Clim., 46, 403-422,
doi:10.1175/Jam2470.1, 2007.

Froyd, K. D., Murphy, D. M., Sanford, T. J., Thomson, D. S., Wilson, J. C., Pfister, L., and Lait, L.: Aerosol composition of the tropical upper troposphere, Atmos. Chem. Phys., 9, 4363-4385, doi:10.5194/acp-9-4363-2009, 2009.

Fueglistaler, S. and Haynes, P. H.: Control of interannual and longer-term variability of stratospheric water vapor, J. Geophys. Res.-Atmos., 110, D24108, doi:10.1029/2005jd006019, 2005.

Fueglistaler, S., Dessler, A. E., Dunkerton, T. J., Folkins, I., Fu, Q., and Mote, P. W.: Tropical Tropopause Layer, Rev. Geophys., 47, Rg1004, doi:10.1029/2008rg000267, 2009.

Gettelman, A., Salby, M., and Sassi, F.: Distribution and influenceof convection in the tropical tropopause region, J. Geophys. Res.Atmos., 107, 4080, doi:10.1029/2001JD001048, 2002.

Gondwe, M., Krol, M., Gieskes, W., Klaassen, W., and de Baar, H.: The contribution of ocean-leaving DMS to the global atmospheric burdens of DMS, MSA, $\mathrm{SO}_{2}$, and $\mathrm{NSS} \mathrm{SO}_{4}^{=}$, Global Biogeochem. Cy., 17, 1056, doi:10.1029/2002gb001937, 2003.

Gray, B. A., Wang, Y., Gu, D., Bandy, A., Mauldin, L., Clarke, A., Alexander, B., and Davis, D. D., Sources, transport, and sinks of $\mathrm{SO}_{2}$ over the equatorial Pacific during the Pacific Atmospheric Sulfur Experiment, J. Atmos. Chem., 201, 27-53, doi:10.1007/s10874-010-9177-7, 2011

Ho, D. T., Law, C. S., Smith, M. J., Schlosser, P., Harvey, M., and Hill, P.: Measurements of air-sea gas exchange at high wind speeds in the Southern Ocean: Implications for global parameterizations, Geophys. Res. Lett., 33, L16611, doi:10.1029/2006g1026817, 2006.

Hofmann, D., Barnes, J., O'Neill, M., Trudeau, M., and Neely, R.: Increase in background stratospheric aerosol observed with lidar at Mauna Loa Observatory and Boulder, Colorado, Geophys. Res. Lett., 36, L15808, doi:10.1029/2009g1039008, 2009.

Kato, S., Ui, T., Uematsu, M., and Kajii, Y.: Trace gas measurements over the northwest Pacific during the 2002 IOC cruise, Geochem. Geophy. Geosy., 8, Q06m10, doi:10.1029/2006gc001241, 2007.

Kettle, A. J. and Andreae, M. O.: Flux of dimethylsulfide from the oceans: A comparison of updated data seas and flux models, J. Geophys. Res.-Atmos., 105, 26793-26808, doi:10.1029/2000jd900252, 2000.

Kettle, A. J., Andreae, M. O., Amouroux, D., Andreae, T. W., Bates, T. S., Berresheim, H., Bingemer, H., Boniforti, R., Curran, M. A. J., DiTullio, G. R., Helas, G., Jones, G. B., Keller, M. D., Kiene, R. P., Leck, C., Levasseur, M., Malin, G., Maspero, M., Matrai, P., McTaggart, A. R., Mihalopoulos, N., Nguyen, B. C., Novo, A., Putaud, J. P., Rapsomanikis, S., Roberts, G., Schebeske, G., Sharma, S., Simo, R., Staubes, R., Turner, S., and Uher, G.: A global database of sea surface dimethylsulfide (DMS) measurements and a procedure to predict sea surface DMS as a function of latitude, longitude, and month, Global Biogeochem. Cy., 13, 399-444, doi:10.1029/1999gb900004, 1999.

Krüger, K. and Quack, B.: Introduction to special issue: the TransBrom Sonne expedition in the tropical West Pacific, Atmos. Chem. Phys. Discuss., 12, 1401-1418, doi:10.5194/acpd-121401-2012, 2012.

Krüger, K., Tegtmeier, S., and Rex, M.: Long-term climatology of air mass transport through the Tropical Tropopause Layer (TTL) during NH winter, Atmos. Chem. Phys., 8, 813-823, doi:10.5194/acp-8-813-2008, 2008. 
Krüger, K., Tegtmeier, S., and Rex, M.: Variability of residence time in the Tropical Tropopause Layer during Northern Hemisphere winter, Atmos. Chem. Phys., 9, 6717-6725, doi:10.5194/acp-96717-2009, 2009.

Lana, A., Bell, T. G., Simo, R., Vallina, S. M., Ballabrera-Poy, J., Kettle, A. J., Dachs, J., Bopp, L., Saltzman, E. S., Stefels, J., Johnson, J. E., and Liss, P. S.: An updated climatology of surface dimethlysulfide concentrations and emission fluxes in the global ocean, Global Biogeochem. Cy., 25, Gb1004, doi:10.1029/2010gb003850, 2011.

Liss, P. S. and Merlivat, L.: Air-sea gas exchange rates: introduction and synthesis, in: The role of air-sea exchange in geochemical cycling, edited by: Buat-Ménard, P., Dordrecht, 113-128, 1986.

Liu, C. T. and Zipser, E. J.: Global distribution of convection penetrating the tropical tropopause, J. Geophys. Res.-Atmos., 110, D23104, doi:10.1029/2005JD006063, 2005.

Lucas, D. D. and Prinn, R. G.: Tropospheric distributions of sulfuric acid-water vapor aerosol nucleation rates from dimethylsulfide oxidation, Geophys. Res. Lett., 30, 2136, doi:10.1029/2003g1018370, 2003.

Marandino, C. A., De Bruyn, W. J., Miller, S. D., and Saltzman, E. S.: Eddy correlation measurements of the air/sea flux of dimethylsulfide over the North Pacific Ocean, J. Geophys. Res.Atmos., 112, D03301, doi:10.1029/2006jd007293, 2007.

Marandino, C. A., De Bruyn, W. J., Miller, S. D., and Saltzman, E. S.: DMS air/sea flux and gas transfer coefficients from the North Atlantic summertime coccolithophore bloom, Geophys. Res. Lett., 35, L23812, doi:10.1029/2008g1036370, 2008.

Myhre, G., Berglen, T. F., Myhre, C. E. L., and Isaksen, I. S. A.: The radiative effect of the anthropogenic influence on the stratospheric sulfate aerosol layer, Tellus B, 56, 294-299, doi:10.1111/j.1600-0889.2004.00106.x, 2004.

Nazaryan, H., McCormick, M. P., and Menzel, W. P.: Global characterization of cirrus clouds using CALIPSO data, J. Geophys. Res.-Atmos., 113, D16211, doi:10.1029/2007JD009481, 2008.

Newell, R. E. and Gould-Stewart, S.: A stratospheric fountain?, J. Atmos. Sci., 38, 2789-2796, 1981.

Osthoff, H. D., Bates, T. S., Johnson, J. E., Kuster, W. C., Goldan, P., Sommariva, R., Williams, E. J., Lerner, B. M., Warneke, C., de Gouw, J. A., Pettersson, A., Baynard, T., Meagher, J. F., Fehsenfeld, F. C., Ravishankara, A. R., and Brown, S. S.: Regional variation of the dimethyl sulfide oxidation mechanism in the summertime marine boundary layer in the Gulf of Maine, J. Geophys. Res.-Atmos., 114, D07301, doi:10.1029/2008jd010990, 2009.

Rex, M., Ridder, T., Notholt, J., Immler, F., Lehmann, R., Krüger, K., Mohr, V., und Tegtmeier, S.: Is there a hole in the global OH shield over the tropical Western Pacific warm pool?, Quadrennial Ozone Symposium, Toronto, 2012.

Ricaud, P., Barret, B., Attié, L., Motte, E., Le Flochmoën, E., Teyssèdre, H., Peuch, V.-H., Livesey, N., Lambert, A., and Pommereau, J.-P.: Impact of land convection on tropospherestratosphere exchange in the tropics, Atmos. Chem. Phys., 7, 5639-5657, doi:10.5194/acp-7-5639-2007, 2007.

Romps, D. M. and Kuang, Z.: Overshooting convection in tropical cyclones, Geophys. Res. Lett., 36, L09804, doi:10.1029/2009GL037396, 2009.

Rossow, W. B. and Pearl, C.: 22-Year survey of tropical convection penetrating into the lower stratosphere, Geophys. Res. Lett., 34, L04803, doi:10.1029/2006GL028635, 2007.
Saltzman, E. S., King, D. B., Holmen, K., and Leck, C.: Experimental determination of the diffusion coefficient of dimethylsulfide in water, J. Geophys. Res., 98, 16481-16486, doi:10.1029/93JC01858, 1993.

Sassen, K., Wang, Z., and Liu, D.: Global distribution of cirrus clouds from CloudSat/CloudAerosol Lidar and Infrared Pathfinder Satellite Observations (CALIPSO) measurements, J. Geophys. Res.-Atmos., 113, D00A12, doi:10.1029/2008JD009972, 2008.

Schauffler, S. M., Atlas, E. L., Blake, D. R., Flocke, F., Lueb, R. A., Lee-Taylor, J. M., Stroud, V., and Travnicek, W.: Distributions of brominated organic compounds in the troposphere and lower stratosphere, J. Geophys. Res.-Atmos., 104, 21513-21535, doi:10.1029/1999jd900197, 1999.

Solomon, S., Daniel, J. S., Neely, R. R., Vernier, J. P., Dutton, E. G., and Thomason, L. W.: The persistently variable "background" stratospheric aerosol layer and global climate change, Science, 333, 866-870, doi:10.1126/science.1206027, 2011.

Spichtinger, N., Wenig, M., James, P., Wagner, T., Platt, U., and Stohl, A.: Satellite detection of a continental-scale plume of nitrogen oxides from boreal forest fires, Geophys. Res. Lett., 28, 4579-4582, doi:10.1029/2001GL013484, 2001.

Stohl, A., and Thomson, D. J.: A density correction for Lagrangian particle dispersion models, Bound-Lay Meteorol., 90, 155-167, doi:10.1023/A:1001741110696, 1999.

Stohl, A. and Trickl, T.: A textbook example of long-range transport: Simultaneous observation of ozone maxima of stratospheric and North American origin in the free troposphere over Europe, J. Geophys. Res.-Atmos., 104, 30445-30462, doi:10.1029/1999jd900803, 1999.

Stohl, A., Hittenberger, M., and Wotawa, G.: Validation of the Lagrangian particle dispersion model FLEXPART against largescale tracer experiment data, Atmos. Environ., 32, 4245-4264, doi:10.1016/S1352-2310(98)00184-8, 1998.

Stohl, A., Forster, C., Eckhardt, S., Spichtinger, N., Huntrieser, H., Heland, J., Schlager, H., Wilhelm, S., Arnold, F., and Cooper, O.: A backward modeling study of intercontinental pollution transport using aircraft measurements, J. Geophys. Res.-Atmos., 108, 4370, doi:10.1029/2002jd002862, 2003.

Stohl, A., Forster, C., Frank, A., Seibert, P., and Wotawa, G.: Technical note: The Lagrangian particle dispersion model FLEXPART version 6.2, Atmos. Chem. Phys., 5, 2461-2474, doi:10.5194/acp-5-2461-2005, 2005.

Tegtmeier, S., Krüger, K., Quack, B., Atlas, E. L., Pisso, I., Stohl, A., and Yang, X.: Emission and transport of bromocarbons: from the West Pacific ocean into the stratosphere, Atmos. Chem. Phys., 12, 10633-10648, doi:10.5194/acp-12-10633-2012, 2012.

Tost, H., Lawrence, M. G., Bruhl, C., Jockel, P., Team, G., and Team, S.-O.-D. A.: Uncertainties in atmospheric chemistry modelling due to convection parameterisations and subsequent scavenging, Atmos. Chem. Phys., 10, 1931-1951, doi:10.5194/acp10-1931-2010, 2010.

Vernier, J.-P., Pommereau, J.-P., Thomason, L. W., Pelon, J., Garnier, A., Deshler, T., Jumelet, J., and Nielsen, J. K.: Overshooting of clean tropospheric air in the tropical lower stratosphere as seen by the CALIPSO lidar, Atmos. Chem. Phys., 11, 96839696, doi:10.5194/acp-11-9683-2011, 2011a.

Vernier, J.-P., Thomason, L. W., Pommereau, J. P., Bourassa, A., Pelon, J., Garnier, A., Hauchecorne, A., Blanot, L., Trepte, 
C., Degenstein, D., and Vargas, F.: Major influence of tropical volcanic eruptions on the stratospheric aerosol layer during the last decade, Geophys. Res. Lett., 38, L12807, doi:10.1029/2011GL047563, 2011b.

Wanninkhof, R.: Relationship between wind-speed and gasexchange over the ocean, J. Geophys. Res.-Oceans., 97, 73737382, doi:10.1029/92jc00188, 1992.

Wofsy, S. C., Daube, B. C., Jimenez, R. Kort, E., Pittman, J. V, Park, S., Commane, R., Xiang, B., Santoni, G., Jacob, D., Fisher, J., Pickett-Heaps, C., Wang, H., Wecht, K., Wang, Q.-Q., Stephens, B. B., Shertz, S., Watt, A. S., Romashkin, P., Campos, T., Haggerty, J., Cooper, W. A., Rogers, D., Beaton, S., Hendershot, R., Elkins, J. W., Fahey, D. W., Gao, R. S., Moore, F., Montzka, S. A., Schwarz, J. P., Perring, A. E., Hurst, D., Miller, B. R., Sweeney, C., Oltmans, S., Nance, D., Hintsa, E., Dutton, G., Watts, L. A., Spackman, J. R., Rosenlof, K. H., Ray, E. A., Hall, B., Zondlo, M. A., Diao, M., Keeling, R., Bent, J., Atlas, E. L., Lueb, R., and Mahoney, M. J.: HIPPO combined discrete flask and GC sample GHG, halo-, hydrocarbon data (R_20121129), Carbon Dioxide Information Analysis Center, Oak Ridge National Laboratory, Oak Ridge, Tennessee, USA, available at: http://dx.doi.org/10.3334/CDIAC/hippo_012 (Release 20121129), 2012.
Zindler, C., Bracher, A., Marandino, C. A., Taylor, B., Torrecilla, E., Kock, A., and Bange, H. W.: Sulphur compounds, methane, and phytoplankton: interactions along a north-south transit in the western Pacific Ocean, Biogeosciences, 10, 3297-3311, doi:10.5194/bg-10-3297-2013, 2013. 